\title{
The Factors Affecting Implementation of Information and Communication Technologies in Rural Secondary Schools in Kenya: The Case of Igembe District, Meru
}

\author{
Mwenda J. Gichuru \\ Meru University of Science and Technology, School of Computing and Informatics, \\ Department of Information Technology, P.O. Box, 1376-60200, Meru, Kenya
}

\begin{abstract}
Information and Communications Technologies (ICTs) in secondary schools entail the convergence of computers, telecommunication devices, Internet of things (IoT) and audio-visual systems. In this study, ICTs were used to mean the use of computer hardware, software, networking and the Internet and other media of communication such as television, radio, newspapers and mobile phones. The objective of the study was to establish the factors that affect the implementation of the ICTs in secondary schools. A census study was conducted at the 40 secondary schools in Igembe district. To collect data the researcher used a structured questionnaire that was personally administered to the respondents. Data was analysed using SPSS and MS-Excel and Friedman's test and factor analysis techniques were used. The factors that affect ICT adoption and implementation were categorized as; inadequate funding, unconducive ICT environment, improper ICT strategies and lack of supportive resources. The researcher identified one of the major factors hindering implementation of ICTs as lack of adequate funding.
\end{abstract}

Keywords: ICTs, Factors, Theories

\section{Introduction}

\subsection{Background}

Information and Communications Technologies (ICTs) entail the convergence of computers, telecommunication and audio-visual systems that enable the collection, processing, transportation and delivery of information and communication services to users. The need for schools to invest in ICT in Kenya has been emphasized by the Kenya Government through the ministry of information. The Government of Kenya recognizes the role of ICTs in the social and economic development of the nation and has promulgated a national ICTs Policy based on the Economic Recovery Strategy for Wealth and Employment Creation (2003-2007) (http://www.information.go.ke). The rationale and implications of the ICT policies in schools can lead to different emphases in the way that ICTs are introduced and used in education, in particular at the secondary school level. ICT is used to refer to the use of computer hardware, software and networking, and other media of communication such as television, radio, and other modes of telecommunications such as mobile phone usage. In this study, the researcher will mainly focus on the use of computers and the Internet for learning. Internet proffers a conveniently accessible and easy-to-use global platform that supports a wide array of learning and knowledge dissemination activities (Allen \& Seaman 2006). In any case digital convergence is bringing all the technologies together through the Internet (Omolo, 2003).

ICTs can support learning by facilitating communication, increase access to information, provide greater learning easiness to students with special education needs, and enhanced students' problem solving capabilities. Successful implementation of ICTs in secondary schools can be achieved through: engaging skilled teachers; employing supportive ICT infrastructure; having access to, and the development and application of online resources and services; instituting enabling policies and strategies that facilitate the uptake and usage of ICT within schools; facilitate Public - private partnerships to mobilize resources; promote the development of integrated e-learning curriculum to support ICT in education; promoting distance education and virtual institutions; facilitate sharing of e-learning resources between institutions; and integrating e-learning resources with other existing resources (Reidlinger and Weir, 1995). According to Ndungu (2005) ICT implementation in high schools is highly influenced by school culture, whole school attitude to ICT, individual attitudes, individual believes, ICT implementation process, access and availability of resources and ICT training and support infrastructure. ICT implementation can be influenced by; availability of funds, electricity, ICT infrastructure, computer resources availability, adequate training of ICT teachers, security, clear government policy, Internet service providers and collaborative support of various stakeholders (Omolo, 2003; Information Communication Technology sector, 2006).

\subsubsection{Implementation of ICTs in Schools}

Implementation involves all the organizational activities working toward the management and routinisation of an innovation (Tornatzky, 1982) which includes the investment of funds into the idea, product or technology (Vasudevan, 2001). Therefore, financial readiness is important for acquisition, training, installation, and maintenance of the ICTs. Regulatory framework is equally important (Watkins, Leigh, and Triner, 2003). ICT sector has been lagging behind in Meru owing to high illiteracy and poverty levels. Internet 


\section{International Journal of Science and Research (IJSR) \\ ISSN (Online): 2319-7064}

Index Copernicus Value (2015): 78.96 | Impact Factor (2015): 6.391

access was negligible with only one Cybercafé in Maua town at the time (Meru North Development Plan, 2002).

\subsection{Statement of the Problem}

The objective of this study is to identify the factors affecting implementation of the ICTs in Igembe secondary schools. Studies which have been previously undertaken relating to ICT implementation in schools left out implementation considerations in rural schools, for instance, Muganda's (2006) study was based in the University of Nairobi, Ndungu's (2005) study was on Kenya high school in Nairobi, and Omolo's (2003) study was on secondary schools in Nairobi. The three researchers suggested further studies to be carried out in rural schools, hence the need for this kind of study.

\subsection{Importance of the Study}

The parents, citizens, school administration, the ministry of education, ICT researchers and consultants may require the predictive information from this study that will give the status of ICT implementation in the rural secondary schools to make their decisions.

\subsection{Factors to consider when implementing ICTs}

Scholars have argued that ICTs as much as they come with advantages they also bring with them a great share of disadvantages. It is widely argued that users who spend most of their time with computers may become socially inactive by becoming individualistic, aggressive and impatient with others (O'Brien, 2002). ICTs may also cause health problems such as carpal turnel syndrome (CTS) and also vision problems (Laudon, 1996). Moreover, use of the Internet for e-learning exposes people to information that could be regarded as immoral. Implementers of e-learning should therefore find ways of restricting access to the Internet. The availability of state-of-the-art hardware and software in the market increases access to technology and thus it can encourage adoption and implementation of ICTs (Obura et al., 2003; Muhunyo, 2008). New technology adoption needs change agents, for instance in secondary schools teachers can be used to create conditions necessary for successful ICTs absorption, adoption and assimilation. Government and school management Support are other necessary conditions for effective implementation of ICT in schools (Mukama and Andersson, 2008).

\section{Theoretical Literature}

Gregor (2002) described theory as a system of rules, principles, a conjecture or an opinion that is regarded and that reports matters of facts. Carbone (2009) describes theoretical framework as the structure of concepts which exist in literature, and that provide the structure and a guide for examining a problem and relationships between variables. The structure of this study will rely on more than one interrelated theoretical frameworks (Mingers, 2001).

\subsection{The Sociological Perspective Theories}

Social cognition produces an innovation concept and the popularity of that concept acts as the channel and driver of the IT innovations diffusion. The impacts of an ICT can be well evaluated through the innovation's fit with the broader business and social environment (Wang, 2009). Information systems research has drawn from social theories such as: Firstly, Institutional theory - concerned with the influences from both internal and external factors that have the potential to shape behavioural, social and organizational structures through coercive, imitative, and normative organizational pressures (Green, 2004; Zhang et al., 2007). Secondly, organizing vision - it is a focal community idea that describes the value, usefulness, tactical or strategic contribution of ICT in a social way, (Wang \& Swanson, 2003; Swanson \& Ramiller, 2004). Lastly, structuration theory - is the most influential and most commonly applied theory in IS research (Desanctis \& Poole, 1994. In the majority of the social perspective theories used in IS/IT adoption research, IT technical aspects are taken for granted, hence the need to use multiple theories in IT studies so as to incorporate the missing IT artefacts (Orlikowski \& Iacono, 2001).

\subsection{The Dominant Paradigm Theories}

Dominant paradigm is an economic-rationalism theory which predicts an accelerated productivity improvement with the cumulative investments in information technology innovations, and thus focuses on factors that influence economic returns to innovation (Fichman; Melville et al., 2004). Dominant paradigm assumes that innovations are good and thus the more innovations the more benefits (Jeyaraj et al., 2006).

\subsubsection{Diffusion of Innovation Theory (DOI)}

The Diffusion of Innovations (DOI) theory explains the variables that influence adoption of new information technologies and also explains how, why and at what rate they spread through an organization or a society over time (Rogers, 1995; Fichman \& Kemerer, 1999). The characteristics perceived to be capable of influencing innovation adoption are (davis 1986; Rogers, 1983; Moore and Benbasat, 1991; Fichman, 1992): relative advantage, compatibility, ease of use, complexity, trialability, demonstrability, image, visibility and voluntariness, relative advantage, complexity and compatibility proffering the most significant explanation for the innovation adoption (Agarwal and Prasad, 1997; Tornatzky \& Klien's, 1982). Organizational and technology adaptor characteristics may also determine diffusion of ICTs, these are; firm size and scope, organizational structure, technological competency, readiness and expected benefits, competitive environment's pressure, industry standards, top management support, championship and organization slack (Green, 2004; Jeyaraj et al., 2006; Melville \& Ramirez, 2008).

\subsubsection{Technology Acceptance Model (TAM)}

Technology Acceptance Model (TAM) predicts a direct positive correlation between beliefs, attitudes and actions (Agarwal \& Prasad, 1997; Melville, 2010). TAM is an intention-based model that predicts user acceptance of 


\section{International Journal of Science and Research (IJSR) \\ ISSN (Online): 2319-7064 \\ Index Copernicus Value (2015): 78.96 | Impact Factor (2015): 6.391}

computer technology, where user acceptance is a critical success factor for IT adoption (Hu et al., 1999). Technology will be extensively adopted and used by schools if it will be viewed as an economical medium that support school activities to bring out the anticipated results, these are; system quality, information quality, user satisfaction, individual impacts, organizational impacts and system use or behaviour (Agarwal \& Prasad, 1997; Kettinger \& Grover, 1997).

\subsubsection{Technology-Organization-Environment (TOE)}

Technology-Organization-Environment (TOE) Framework describes the process of technological innovation (Tornatzky \& Fleischer, 1990; Lippert \& Govindarajulu, 2006) and can help in the study of the adoption of technological innovations in schools (Zhang et al., 2007). TOE posits that technology context, organization context, and environment context influence adoption and implementation of relevant technologies in areas such as education. Technological context encompasses the available technologies, equipment and processes that are important for the organization's productivity. Organizational context entails the characteristics and available resources of an organization that are capable of supporting adoption of innovations, while the environmental context may include the government influence like in government-sponsored secondary schools (DePietro et al., 1990; Lippert \& Govindarajulu, 2006; Zhang et al., 2007).

\subsection{Empirical Literature}

Some of the studies that have used DOI to explain adoption and implementation of ICT are; Bradford \& Florin (2003); Mustonen-Ollila \& Lyytinen (2003); Cooper \& Zmud (1990); Brancheau \& Wetherbe (1990); and Greenhalgh et al. (2004). Some of the recent studies that have used TAM to explain ICT adoption and implementation are; Chan \& Lu (2004); King \& He (2006); and Bradley \& Lee (2007). The studies that used TAM in learning environments are; Park (2009); Lau \& Woods (2008); Hu, Clark, \& Ma (2003). TOE as a model has been used to study factors affecting adoption and implementation of ICTs in organizations; Lee \& Shim (2007); Zhang, Cui, Huang and Zhang (2007); Henriksen (2006); and Pan \& Jang (2008). Studies that used institutional theory are; Jeyaraj, Rottman, Lacity (2006); and Zhang, Cui, Huang, and Zhang (2007). Lastly there is one study that used organizing vision by Klecun-Dabrowska \& Cornford (2002).

Table 1: Summary of empirical studies

\begin{tabular}{|c|c|c|c|c|}
\hline Study & Purpose of the Study & $\begin{array}{l}\text { Theories } \\
\text { applied }\end{array}$ & Main Findings & Gap \\
\hline $\begin{array}{c}\text { Attewell, P., } \\
1992\end{array}$ & $\begin{array}{l}\text { Technology diffusion and } \\
\text { organizational learning }\end{array}$ & $\begin{array}{c}\text { DOI } \\
\text { Interviews }\end{array}$ & $\begin{array}{c}\text { A theoretical framework for examining the } \\
\text { diffusion of complex production } \\
\text { technologies was developed }\end{array}$ & $\begin{array}{l}\text { Knowledge barrier approach } \\
\text { to technology diffusion as a } \\
\text { distinct theory in its own right }\end{array}$ \\
\hline $\begin{array}{l}\text { Park, S. Y. } \\
\text { (2009) }\end{array}$ & $\begin{array}{l}\text { An analysis of the technology } \\
\text { acceptance model in } \\
\text { understanding university } \\
\text { students' behavioural intention } \\
\text { to use e-learning }\end{array}$ & $\begin{array}{l}\text { Structural } \\
\text { Equation } \\
\text { Modeling } \\
\text { (SEM), TAM } \\
\text { Questionnaire }\end{array}$ & $\begin{array}{l}\text { Confirmed TAM to be useful model in } \\
\text { helping understanding and explaining } \\
\text { pehavioural intention to use e-learning. Both } \\
\text { e-learning self-efficacy and subjective norm } \\
\text { influence attitude towards e-learning and } \\
\text { behavioural intention to use e-learning }\end{array}$ & $\begin{array}{l}\text { carry out similar study on } \\
\text { blended learning or } \\
\text { synchronous e-learning }\end{array}$ \\
\hline $\begin{array}{l}\text { Lau, S. \& } \\
\text { Woods, P. C. } \\
\quad(2008)\end{array}$ & $\begin{array}{l}\text { An investigation of user } \\
\text { perceptions and attitudes } \\
\text { towards learning objects }\end{array}$ & $\begin{array}{l}\text { TAM, } \\
\text { TRA } \\
\text { Web-based } \\
\text { survey }\end{array}$ & $\begin{array}{l}\text { The user beliefs and attitudes have } \\
\text { significant positive relationships with } \\
\text { behavioural intention, which in turn helps } \\
\text { predicting the actual use of learning objects. } \\
\text { TAM was validated as a useful model in } \\
\text { predicting user's future behaviour }\end{array}$ & $\begin{array}{l}\text { There is need for a longitudinal } \\
\text { approach other than a snapshot } \\
\text { study conducted and include } \\
\text { other areas of study }\end{array}$ \\
\hline $\begin{array}{l}\text { Seers, A. } \\
(2007)\end{array}$ & $\begin{array}{l}\text { Management education in the } \\
\text { merging knowledge economy: } \\
\text { Going beyond those "who can, } \\
\text { do; those who can't, teach" }\end{array}$ & $\begin{array}{l}\text { Exploratory } \\
\text { study }\end{array}$ & $\begin{array}{l}\text { What holds and does not hold anymore in } \\
\text { management education due to the } \\
\text { transformation being caused by the } \\
\text { emerging knowledge economy }\end{array}$ & $\begin{array}{l}\text { To study into the precise } \\
\text { forms of organizations as a } \\
\text { result of the transformation in } \\
\text { the knowledge economy }\end{array}$ \\
\hline $\begin{array}{l}\text { Chau, P. Y. } \\
\text { K. \& Hu, P. J. } \\
\quad(2001)\end{array}$ & $\begin{array}{l}\text { Information Technology } \\
\text { acceptance by individual } \\
\text { professionals: A model } \\
\text { comparison approach }\end{array}$ & $\begin{array}{c}\text { TAM, } \\
\text { TPB } \\
\text { Questionnaire } \\
\text { survey }\end{array}$ & $\begin{array}{l}\text { Perceived usefulness and attitude were } \\
\text { found to be the most significant factors for } \\
\text { physicians' acceptance of telemedicine } \\
\text { technology, and PEU had no significant } \\
\text { effect on PU and attitude. Compatibility s } \\
\text { significant in predicts PU }\end{array}$ & $\begin{array}{l}\text { Additional factors over the } \\
\text { TAM and TPB factors to help } \\
\text { counter constraints } \\
\text { encountered in predicting } \\
\text { technology acceptance by } \\
\text { individual professionals }\end{array}$ \\
\hline $\begin{array}{l}\text { Klecun- } \\
\text { Dabrowska, } \\
\text { E. \& } \\
\text { Cornford, T. } \\
\text { (2002) }\end{array}$ & $\begin{array}{l}\text { The Organising vision of } \\
\text { Telehealth }\end{array}$ & $\begin{array}{l}\text { Organising } \\
\text { Vision } \\
\text { Interviews }\end{array}$ & $\begin{array}{l}\text { Found out that the organizing vision of } \\
\text { Telehealth is compelling }\end{array}$ & $\begin{array}{l}\text { Positive experience of } \\
\text { telehealth initiatives may not } \\
\text { be transferable between } \\
\text { countries, regions, individual } \\
\text { institutions or projects, thus } \\
\text { requiring validating }\end{array}$ \\
\hline $\begin{array}{l}\text { Jeyaraj, A., } \\
\text { Rottman, J. } \\
\text { W., Lacity, } \\
\text { M. C. (2006) } \\
\end{array}$ & $\begin{array}{l}\text { A Review of the predictors, } \\
\text { linkages, and biases in IT } \\
\text { innovation adoption research }\end{array}$ & $\begin{array}{l}\text { TAM/TAM2/ } \\
\text { DOI } \\
\text { Social } \\
\text { Cognitive } \\
\end{array}$ & $\begin{array}{c}\text { Dominant paradigm for the adoption of ICT } \\
\text { nnovations by individuals and organizations } \\
\text { continue to make significant progress. }\end{array}$ & $\begin{array}{l}\text { Explore boundaries within } \\
\text { and outside the dominant } \\
\text { paradigm }\end{array}$ \\
\hline
\end{tabular}




\section{International Journal of Science and Research (IJSR)}

ISSN (Online): 2319-7064

Index Copernicus Value (2015): 78.96 | Impact Factor (2015): 6.391

\begin{tabular}{|c|c|c|c|c|}
\hline & & Theory & & \\
\hline $\begin{array}{l}\text { Zhang, C., } \\
\text { Cui, L., } \\
\text { Huang, L., } \\
\text { and Zhang, C. } \\
\text { (2007) }\end{array}$ & $\begin{array}{c}\text { Exploring the role of } \\
\text { Government in information } \\
\text { Technology diffusion: An } \\
\text { empirical study of IT Usage in } \\
\text { shanghai firms }\end{array}$ & $\begin{array}{c}\text { TOE } \\
\text { Institutional } \\
\text { Theory }\end{array}$ & $\begin{array}{l}\text { In-depth examination of government impact } \\
\text { on IT adoption in either national, semi- } \\
\text { national and private institutions } \\
\text { Results suggest environmental factors like } \\
\text { government policies }\end{array}$ & $\begin{array}{l}\text { Study to focus various } \\
\text { industries and other } \\
\text { economies such the } \\
\text { developing countries }\end{array}$ \\
\hline
\end{tabular}

\section{Research Methodology}

\subsection{Research Design}

The survey research design was used for this study to establish and describe the factors affecting adoption and implementation of ICTs in secondary schools in Igembe district. Survey research is appropriate for collecting data from members of a population and describing existing phenomena by asking individuals about their opinion, attitudes, behavior or values, and then summarizing and reporting the way things are (Mugenda \& Mugenda, 1999; 2003). It is often used to study the general condition of people and organizations as it investigates the behavior and opinion of people usually through questioning them (Cooper and Schindler, 2003).

\subsection{Target Population, Sampling Design and Data Collection Technique}

The target population for this study was all the 40 secondary schools in Igembe district. The respondents were the school principals or their representatives who could be either the computer studies teacher or any other teacher who is knowledgeable in ICT in the respective secondary schools, therefore researcher's own insight was exercised and thus judgmental method was used to select the appropriate respondents in this study. According to Mugenda \& Mugenda (2003) when target population is small a census study is preferred to sampling, hence a census study was done. Mugenda \& Mugenda (2003) defines sampling as the process of selecting a number of individuals for a study in such a way that the individual selected is representative of the large group from which they are selected. In this study there was no need for sampling since it was a survey study involving all the elements in the population. The researcher used a structured questionnaire for data collection. The questionnaires were personally administered to the respondents, where a principal or his/her representative filled a questionnaire in each and every school in Igembe district. This method was appropriate since it encouraged prompt responses from the respondents and helped addressing the specific objective of the study (Mugenda \& Mugenda, 2003). The questionnaire was structured in such a way that it could capture the data on factors that influence ICT implementation in secondary schools.

\subsection{Data Analysis}

Quantitative data collected was analysed using SPSS software and Microsoft Excel, this enabled data interpretation and making of statistical inferences. The collected data were coded, tabulated and then analysed using descriptive statistics, Friedman's test and factor analysis techniques. The factor analysis and Friedman's test techniques were used to determine the factors that affect ICT implementation and the relative importance of those factors.

\section{Findings}

\subsection{Introduction}

This section entails data analysis and interpretation of the research findings. The section therefore documents the factors that affect the implementation of ICTs in Igembe secondary schools. Out of the forty secondary schools targeted, only two schools were not reached to provide response. Therefore, the response rate was at $95 \%$.

\subsection{The factors Affecting ICT implementation in Secondary Schools}

\subsubsection{Factor Analysis: Factors Summaries and Component Grouping}

Factor analysis was performed on the factors affecting the implementation of ICTs in Igembe Secondary schools. Initially, correlation analysis was run to check for interdependence among the factors after which Principal Component Analysis (PCA) was run to transform a set of interrelated variables into a set of unrelated or uncorrelated linear combinations of the variables. From the correlation matrix, the correlation coefficients were more close to 1 meaning that there is a relationship between the variables. Varimax rotation together with Kaiser Criterion were used to classify and reduce the factors to interpretable components.

Table 2 represents the communalities for factors that affect the ICTs implementation in secondary schools. The communality is the squared multiple correlation coefficient for variables using the factors as predictors. The communality measures the percentage of variance in a given variable explained by all the factors jointly and can be interpreted as the reliability of the indicator. It is the proportion of variance that each item or variable has in common with other items. For instance, $92.3 \%$ of is the highest variability in the factor "Readily available Internet Service Providers", while as the lowest variability was captured for the factor "Staff participation in Planning and implementation" with a communality of $67.5 \%$.

Table 2: Rescaled Communality

\begin{tabular}{|c|c|c|}
\hline Factors & Initial & Extraction \\
\hline $\begin{array}{c}\text { Reliable Telecommunication links or } \\
\text { Telephone lines }\end{array}$ & 1.000 & .700 \\
\hline Acquisition of Computer Hardware & 1.000 & .881 \\
\hline Acquisition of Computer Software & 1.000 & .910 \\
\hline Subscription to relevant sites & 1.000 & .768 \\
\hline $\begin{array}{c}\text { Availability of appropriate ICT Media (e.g. } \\
\text { Internet, Mobile phones) }\end{array}$ & 1.000 & .706 \\
\hline Availability of an elaborate ICT Curriculum & 1.000 & .778 \\
\hline Formulation of Appropriate ICT Policy & 1.000 & .797 \\
\hline Availability of adequate Class room space & 1.000 & .826 \\
\hline
\end{tabular}

Volume 6 Issue 1, January 2017 


\section{International Journal of Science and Research (IJSR) \\ ISSN (Online): 2319-7064}

Index Copernicus Value (2015): 78.96 | Impact Factor (2015): 6.391

\begin{tabular}{|c|c|c|}
\hline $\begin{array}{c}\text { Government Funding to acquire ICT } \\
\text { Equipment }\end{array}$ & 1.000 & .802 \\
\hline $\begin{array}{l}\text { Involvement of NGOs in ICT } \\
\text { implementation }\end{array}$ & 1.000 & .738 \\
\hline $\begin{array}{c}\text { Staff participation in Planning and } \\
\text { implementation }\end{array}$ & 1.000 & .675 \\
\hline $\begin{array}{l}\text { ICT Equipment Vendors' and Consultants' } \\
\text { advice and their availability }\end{array}$ & 1.000 & .780 \\
\hline $\begin{array}{l}\text { Security and Safety around and within the } \\
\text { School }\end{array}$ & 1.000 & .730 \\
\hline $\begin{array}{c}\text { Competent ICT Staff (e.g. Teachers, Support } \\
\text { staff) }\end{array}$ & 1.000 & .845 \\
\hline Funds availability for ICTs implementation & 1.000 & .737 \\
\hline $\begin{array}{l}\text { Availability of Uninterrupted Electricity } \\
\text { supply }\end{array}$ & 1.000 & .698 \\
\hline Alternative Power supply (e.g. Generators) & 1.000 & .850 \\
\hline The Ministry of Education's Support & 1.000 & .868 \\
\hline The School Administration's Support & 1.000 & .839 \\
\hline Students' interest and Motivation & 1.000 & .906 \\
\hline Teachers' Motivation and regular training & 1.000 & .799 \\
\hline Readily available Internet Service Providers' & 1.000 & .923 \\
\hline $\begin{array}{c}\text { Sufficient Bandwidth for Adequate Internet } \\
\text { services }\end{array}$ & 1.000 & .894 \\
\hline Proper Road Networks to the School & 1.000 & .783 \\
\hline $\begin{array}{c}\text { Sieving strategies against insecure sites and } \\
\text { immoral materials on the Internet }\end{array}$ & 1.000 & .824 \\
\hline
\end{tabular}

\begin{tabular}{|c|c|c|}
\hline Proper policies to protect Intellectual Rights & 1.000 & .742 \\
\hline Literacy of the neighbouring community & 1.000 & .819 \\
\hline $\begin{array}{c}\text { Relative wealth of the neighbouring } \\
\text { community }\end{array}$ & 1.000 & .882 \\
\hline
\end{tabular}

Table 3 indicates the total variance explained by each component (factor). A total of 9 components were extracted from the factors. The components are orthogonal to one another, meaning they are uncorrelated. For a component to account for at least one variable, it should have an Eigen value (the sum of squares of its factor loadings) of at least one. This is the cut off point for determining the number of components to be extracted with maximum or near maximum loadings (as defined by Kaiser Criteria). Component 1 explains the highest observed variance followed by component 2 and so on. From the table, component 1 accounts for $25.685 \%$ of the total observed variability while component 2 explains $11.453 \%$, component three $9.4 \%$, component four $8.161 \%$, component five $6.31 \%$, component six 5.412\%, component seven $5.366 \%$, component eight $4.542 \%$, and component nine $4.037 \%$. The nine extracted components explain $80.366 \%$ of the total variability for all the 28 variables.

Table 3: Total Variance Explained

\begin{tabular}{|c|c|c|c|c|c|c|c|c|c|}
\hline \multirow[b]{2}{*}{ Component } & \multicolumn{3}{|c|}{ Initial Eigen values } & \multicolumn{3}{|c|}{ Extraction Sums of Squared Loadings } & \multicolumn{3}{|c|}{ Rotation Sums of Squared Loadings } \\
\hline & Total & $\begin{array}{c}\% \text { of } \\
\text { Variance }\end{array}$ & $\begin{array}{c}\text { Cumulative } \\
\%\end{array}$ & Total & $\begin{array}{c}\% \text { of } \\
\text { Variance }\end{array}$ & $\begin{array}{c}\text { Cumulative } \\
\%\end{array}$ & Total & $\begin{array}{c}\% \text { of } \\
\text { Variance }\end{array}$ & $\begin{array}{c}\text { Cumulative } \\
\%\end{array}$ \\
\hline 1 & 7.192 & 25.685 & 25.685 & 7.192 & 25.685 & 25.685 & 3.938 & 14.064 & 14.064 \\
\hline 2 & 3.207 & 11.453 & 37.138 & 3.207 & 11.453 & 37.138 & 3.405 & 12.162 & 26.226 \\
\hline 3 & 2.632 & 9.400 & 46.538 & 2.632 & 9.400 & 46.538 & 2.562 & 9.149 & 35.375 \\
\hline 4 & 2.285 & 8.161 & 54.698 & 2.285 & 8.161 & 54.698 & 2.477 & 8.847 & 44.222 \\
\hline 5 & 1.767 & 6.310 & 61.008 & 1.767 & 6.310 & 61.008 & 2.254 & 8.050 & 52.273 \\
\hline 6 & 1.515 & 5.412 & 66.421 & 1.515 & 5.412 & 66.421 & 2.240 & 8.000 & 60.273 \\
\hline 7 & 1.502 & 5.366 & 71.787 & 1.502 & 5.366 & 71.787 & 2.029 & 7.246 & 67.518 \\
\hline 8 & 1.272 & 4.542 & 76.329 & 1.272 & 4.542 & 76.329 & 1.864 & 6.657 & 74.175 \\
\hline 9 & 1.130 & 4.037 & 80.366 & 1.130 & 4.037 & 80.366 & 1.733 & 6.191 & 80.366 \\
\hline 10 & .824 & 2.944 & 83.310 & & & & & & \\
\hline 11 & .781 & 2.789 & 86.099 & & & & & & \\
\hline 12 & .665 & 2.376 & 88.475 & & & & & & \\
\hline 13 & .537 & 1.917 & 90.392 & & & & & & \\
\hline 14 & .463 & 1.653 & 92.045 & & & & & & \\
\hline 15 & .389 & 1.390 & 93.435 & & & & & & \\
\hline 16 & .371 & 1.327 & 94.762 & & & & & & \\
\hline 17 & .306 & 1.093 & 95.855 & & & & & & \\
\hline 18 & .275 & .982 & 96.837 & & & & & & \\
\hline 19 & .214 & .765 & 97.602 & & & & & & \\
\hline 20 & .165 & .590 & 98.192 & & & & & & \\
\hline 21 & .145 & .519 & 98.711 & & & & & & \\
\hline 22 & .127 & .454 & 99.165 & & & & & & \\
\hline 23 & .087 & .310 & 99.475 & & & & & & \\
\hline 24 & .066 & .235 & 99.710 & & & & & & \\
\hline 25 & .033 & .117 & 99.827 & & & & & & \\
\hline 26 & .021 & .073 & 99.901 & & & & & & \\
\hline 27 & .017 & .059 & 99.960 & & & & & & \\
\hline 28 & .011 & .040 & 100.000 & & & & & & \\
\hline
\end{tabular}

Volume 6 Issue 1, January 2017 www.ijsr.net

Licensed Under Creative Commons Attribution CC BY 


\section{International Journal of Science and Research (IJSR) \\ ISSN (Online): 2319-7064 \\ Index Copernicus Value (2015): 78.96 | Impact Factor (2015): 6.391}

Table 4: Rotated Component Matrix (a)

\begin{tabular}{|c|c|c|c|c|c|c|c|c|c|}
\hline \multirow{2}{*}{ Factors } & \multicolumn{9}{|c|}{ Component } \\
\hline & 1 & 2 & 3 & 4 & 5 & 6 & 7 & 8 & 9 \\
\hline Reliable Telecommunication links & -0.09 & -0.183 & -0.012 & 0.126 & -0.106 & 0.108 & -0.316 & 0.661 & 0.286 \\
\hline Acquisition of Computer Hardware & 0.892 & 0.143 & -0.013 & 0.184 & 0.126 & 0.032 & 0.075 & -0.016 & -0.091 \\
\hline Acquisition of Computer Software & 0.896 & 0.052 & -0.05 & 0.115 & 0.107 & 0.12 & 0.045 & 0.071 & -0.234 \\
\hline Subscription to relevant sites & -0.014 & 0.624 & -0.215 & 0.528 & -0.115 & 0.147 & 0.059 & 0.091 & -0.085 \\
\hline Availability of appropriate ICT Media & -0.123 & 0.032 & -0.014 & 0.113 & 0.176 & -0.036 & -0.09 & 0.043 & 0.797 \\
\hline Availability of an elaborate ICT Curriculum & 0.425 & 0.189 & 0.13 & 0.591 & -0.131 & 0.371 & 0.079 & -0.149 & 0.112 \\
\hline Formulation of Appropriate ICT Policy & 0.615 & 0.118 & 0.321 & -0.03 & -0.447 & 0.18 & 0.126 & 0.058 & 0.222 \\
\hline Availability of adequate Class room space & 0.375 & 0.271 & 0.153 & 0.123 & -0.083 & -0.015 & 0.053 & 0.668 & -0.344 \\
\hline Government Funding to acquire ICT Equipment & 0.152 & 0.116 & 0.027 & 0.098 & -0.057 & 0.852 & 0.017 & 0.135 & 0.091 \\
\hline Involvement of NGOs in ICT implementation & 0.268 & 0.053 & 0.394 & 0.703 & 0.064 & 0.082 & 0.031 & -0.047 & 0.012 \\
\hline Staff participation in Planning and implementation & -0.039 & 0.204 & 0.099 & 0.605 & -0.047 & 0.083 & 0.178 & 0.24 & 0.398 \\
\hline ICT Equipment Vendors' and Consultants' availability & -0.021 & 0.332 & -0.004 & 0.145 & -0.066 & 0.26 & 0.758 & 0.008 & -0.035 \\
\hline Security and Safety around and within the School & 0.204 & 0.085 & 0.275 & 0.142 & 0.203 & -0.063 & 0.657 & -0.084 & -0.32 \\
\hline Competent ICT Staff & 0.427 & -0.127 & -0.179 & 0.463 & -0.261 & 0.429 & 0.264 & 0.248 & -0.13 \\
\hline Funds availability for ICTs implementation & 0.713 & -0.089 & 0.3 & 0.028 & -0.009 & 0.198 & 0.02 & 0.286 & 0.09 \\
\hline Availability of Uninterrupted Electricity supply & 0.521 & 0.126 & 0.391 & 0.173 & -0.142 & -0.102 & 0.311 & 0.089 & -0.304 \\
\hline Alternative Power supply & 0.282 & 0.168 & 0.037 & -0.255 & 0.189 & 0.405 & 0.192 & 0.644 & 0.158 \\
\hline The Ministry of Education's Support & 0.199 & 0.09 & 0.4 & 0.305 & 0.131 & 0.699 & -0.047 & 0.095 & -0.224 \\
\hline The School Administration's Support & 0.09 & -0.062 & 0.833 & 0.27 & 0.103 & 0.097 & 0.017 & 0.098 & -0.174 \\
\hline Students' interest and Motivation & 0.086 & -0.022 & 0.916 & -0.03 & 0.07 & 0.053 & 0.174 & 0.01 & 0.143 \\
\hline Teachers' Motivation and regular training & 0.143 & 0.334 & 0.145 & 0.419 & 0.196 & 0.092 & 0.334 & 0.449 & -0.331 \\
\hline Readily available Internet Service Providers' & 0.164 & 0.884 & -0.019 & 0.059 & -0.141 & 0.217 & 0.192 & 0.002 & -0.08 \\
\hline Sufficient Bandwidth for Adequate Internet services & 0.469 & 0.671 & 0.287 & -0.261 & -0.104 & 0.036 & 0.196 & -0.15 & -0.035 \\
\hline Proper Road Networks to the School & 0.23 & -0.202 & 0.145 & -0.039 & 0.166 & -0.427 & 0.626 & 0.005 & 0.255 \\
\hline $\begin{array}{l}\text { Sieving against insecure sites and immoral materials on the } \\
\text { Internet }\end{array}$ & -0.054 & 0.852 & -0.077 & 0.195 & -0.077 & 0.042 & -0.051 & 0.155 & 0.129 \\
\hline Proper policies to protect Intellectual Rights & 0.023 & 0.597 & 0.101 & 0.022 & 0.579 & -0.173 & 0.085 & -0.044 & 0.014 \\
\hline Literacy of the neighbouring community & -0.157 & -0.326 & 0.102 & -0.268 & 0.747 & 0.182 & -0.013 & 0.122 & -0.003 \\
\hline Relative wealth of the neighbouring community & 0.18 & -0.077 & 0.084 & 0.102 & 0.86 & -0.076 & 0.144 & -0.076 & 0.231 \\
\hline
\end{tabular}

Table 4 presents the rotated component matrix that was used to extract independent variables highly related to particular components. Orthogonal Varimax rotation together with the Kaiser Normalization were used to force the entries in the initial factor to be near 0 or 1 . Such loadings show more clearly which variables go together and thus easily interpretable. The final matrix represents both a pattern and a structure matrix. The coefficients in the rotated matrix indicate both the correlation coefficient and the regression weights. Components 1 to 9 in table 4 respectively represent acquisition of ICT resources and their support, Internet services accessibility and strategies, human attitude and social forces, collective participation, the schools' external environment the government's support, supportive services, ICT infrastructure, and ICT Media

availability. The factor loading heavily on a particular component should have the greatest corresponding value entry across all the nine components in the rotated component matrix. A summary of the factor loading heavily to a particular component is shown in Table 5. The first two components clearly indicate that the most important factors that affect ICT implementation in secondary schools relate to acquisition of ICT resources and their support and Internet services accessibility and strategies. The variables extracted under the nine factors are as follows: Component 1(Acquisition of ICT resources and their support) consists of acquisition of computer hardware and software, funds availability for ICTs implementation, availability of uninterrupted electricity supply, and formulation of appropriate ICT policy; Component 2 (Internet services accessibility and strategies) consists of subscription to the relevant sites, readily available Internet service providers, sieving strategies against insecure sites and immoral materials on the Internet, sufficient bandwidth for adequate Internet services, and proper policies to protect Intellectual rights; Component 3 (Human attitude and social forces) consists of the school administration's support, and students' interest and motivation; Components 4 (Collective participation) consists of involvement of NGOs, and staff participation in planning and implementation; Component 5 (The schools' external environment) consists of literacy of the neighbouring community, and relative wealth of the neighbouring community; Component 6 (The government's support) consists of government funding to acquire ICT equipment, and the ministry of education's support; Component 7 (Supportive services) involves the ICT equipment vendors and consultants availability, security and safety around and within the school, and proper road networks to the school; Component 8 (ICT infrastructure) consists of reliable telecommunication links, availability of adequate class room space; and alternative power supply and; Component 9 (ICT Media availability) involves the availability of the appropriate ICT media.

Table 5: Summary of heavy loading components

\begin{tabular}{|c|c|c|c|}
\hline Component & \multicolumn{3}{|c|}{ Initial Eigen values } \\
\hline & Total & \% of Variance & Cumulative \% \\
\hline 1 & 7.192 & 25.685 & 25.685 \\
\hline 2 & 3.207 & 11.453 & 37.138 \\
\hline 3 & 2.632 & 9.400 & 46.538 \\
\hline 4 & 2.285 & 8.161 & 54.698 \\
\hline
\end{tabular}

\section{Volume 6 Issue 1, January 2017}


International Journal of Science and Research (IJSR)

ISSN (Online): 2319-7064

Index Copernicus Value (2015): 78.96 | Impact Factor (2015): 6.391

\begin{tabular}{|l|l|l|l|}
\hline 5 & 1.767 & 6.310 & 61.008 \\
\hline 6 & 1.515 & 5.412 & 66.421 \\
\hline 7 & 1.502 & 5.366 & 71.787 \\
\hline 8 & 1.272 & 4.542 & 76.329 \\
\hline 9 & 1.130 & 4.037 & 80.366 \\
\hline
\end{tabular}

4.4.2 The factors Affecting ICT implementation in Igembe Secondary schools.

Table 6: The Friedman's Factor Ranking

\begin{tabular}{|c|c|c|c|}
\hline Factors & Mean & $\begin{array}{l}\text { Std. } \\
\text { Dev. }\end{array}$ & Rank \\
\hline Students' interest and Motivation & 3.37 & 1.4411 & 1 \\
\hline Proper Road Networks to the School & 3.50 & 1.4285 & 2 \\
\hline Reliable Telecommunication links & 3.39 & 1.4054 & 3 \\
\hline $\begin{array}{l}\text { Security and Safety around and within } \\
\text { the School }\end{array}$ & 3.16 & 1.1974 & 4 \\
\hline $\begin{array}{l}\text { Relative wealth of the neighbouring } \\
\text { community }\end{array}$ & 3.08 & 0.9118 & 5 \\
\hline The School Administration's Support & 3.00 & 1.3755 & 6 \\
\hline iteracy of the neighbouring community & 3.00 & 1.0134 & 7 \\
\hline Availability of appropriate ICT Media & 2.87 & 1.2980 & 8 \\
\hline $\begin{array}{c}\text { Availability of adequate Class room } \\
\text { space }\end{array}$ & 2.58 & 1.3483 & 9 \\
\hline $\begin{array}{c}\text { Staff participation in Planning and } \\
\text { implementation }\end{array}$ & 2.47 & 1.2463 & 10 \\
\hline $\begin{array}{l}\text { Funds availability for ICTs } \\
\text { implementation }\end{array}$ & 2.45 & 1.4832 & 11 \\
\hline $\begin{array}{c}\text { CT Equipment Vendors' \&Consultants' } \\
\text { availability } \\
\end{array}$ & 2.32 & 1.2543 & 12 \\
\hline $\begin{array}{c}\text { Availability of Uninterrupted Electricity } \\
\text { supply }\end{array}$ & 2.45 & 1.6878 & 13 \\
\hline $\begin{array}{c}\text { Involvement of NGOs in ICT } \\
\text { implementation }\end{array}$ & 2.37 & 1.5143 & 14 \\
\hline The Ministry of Education's Support & 2.26 & 1.3087 & 15 \\
\hline Competent ICT Staff & 2.18 & 1.4305 & 16 \\
\hline Alternative Power supply & 2.34 & 1.6970 & 17 \\
\hline $\begin{array}{c}\text { Teachers' Motivation and regular } \\
\text { training }\end{array}$ & 2.13 & 1.3788 & 18 \\
\hline $\begin{array}{l}\text { Availability of an elaborate ICT } \\
\text { Curriculum }\end{array}$ & 2.11 & 1.3109 & 19 \\
\hline $\begin{array}{c}\text { Government Funding to acquire ICT } \\
\text { Equipment }\end{array}$ & 2.00 & 1.2734 & 20 \\
\hline Formulation of Appropriate ICT Policy & 2.05 & 1.2509 & 21 \\
\hline Acquisition of Computer Hardware & 1.82 & 1.2489 & 22 \\
\hline Acquisition of Computer Software & 1.76 & 1.1954 & 23 \\
\hline $\begin{array}{l}\text { Sieving against insecure sites and } \\
\text { immoral materials on the Internet }\end{array}$ & 1.50 & 0.9515 & 24 \\
\hline $\begin{array}{c}\text { Proper policies to protect Intellectual } \\
\text { Rights }\end{array}$ & 1.42 & 1.0301 & 25 \\
\hline Subscription to relevant sites & 1.29 & 0.7679 & 26 \\
\hline Readily available ISP & 1.24 & 0.5897 & 27 \\
\hline $\begin{array}{l}\text { Sufficient Bandwidth for Adequate } \\
\text { Internet services }\end{array}$ & 1.13 & 0.4140 & 28 \\
\hline
\end{tabular}

Table 6 is based on Friedman rank test, the test assigns weights based on the degree of importance of factors (i.e. most important to least important). Table 6 ranked factors as; factors 1 to 15 were the most important factors, factors 16 to 23 were averagely important, while factors 24 to 28 were of no consequence to secondary schools, whilst factor 24 to 28 lacked significance because of the absence of Internet connection in the schools.

\section{Conclusions and Recommendations}

\subsection{Introduction}

The objective of this study was to identify the factors that greatly influence the implementation of the ICTs in secondary schools. This chapter presents the summary, discussions and conclusions from the research findings as per the objective of the study. The limitations of the study as well as suggestions for further research have also been discussed.

\subsection{Summary, Discussions and Conclusions}

Results of factor analysis revealed that the most salient factors were; acquisition of ICT resources and their support, Internet services accessibility and strategies, the human attitudes and social forces, schools' external environment, government's support, supportive services, ICT infrastructure, and lastly the ICT media availability. Friedman's ranking was used to determine the importance of the individual factors that influence the ICT implementation in secondary schools in Igembe district. The factors that were considered were; security and safety in the schools, relative wealth of the community, the school top management support, literacy of the neighbouring community, availability of appropriate ICT media, availability of class room space, staff participation in planning and implementation, ministry of education support, ICT equipment vendors and consultants advice and availability, availability of uninterrupted electricity supply, involvement of NGOs in ICT implementation, and schools capability to fund ICT implementation.

\subsection{Recommendations}

The study found out that the factors affecting ICT implementation in secondary schools are majorly related to financial, organizational, technical and social factors, though the major one was lack of funds. Therefore, the researcher recommends that the government and NGOs should develop an affirmative action geared towards automation of education systems by providing finances and other supportive resources.

\subsection{Limitations of the Study}

The researcher spent more time, effort and money beyond the expected while administering the questionnaires because majority of the school principals were ignorant and naïve about the concepts being tested and in spite of lengthy explanations, they insisted on remaining with the questionnaire forcing the researcher to make several trips to the schools. Most of the secondary schools were remotely and sparsely located and thus required that the researcher travel for long distances, some of those places did not have means of transport hence had to walk through hilly and rocky roads to the schools.

\subsection{Suggestions for Further Research}

This study was conducted on rural secondary schools in Igembe district. There is need for subsequent longitudinal

\section{Volume 6 Issue 1, January 2017




\section{International Journal of Science and Research (IJSR) \\ ISSN (Online): 2319-7064}

Index Copernicus Value (2015): 78.96 | Impact Factor (2015): 6.391

researches to study the trends in ICTs implementation in secondary schools in the district. Furthermore, ICT field is dynamic and therefore a research on the same area could be repeated after a period of say 5 years to establish any trends that are likely to emerge. The study was restricted to only one district and the population was rather relatively small and thus the study on ICT implementation in rural secondary schools can be repeated in other districts to enable proper generalization of the findings.

\section{References}

[1] Allen, I. E. \& Seaman, J. (2006). Making The Grade: Online Education in the United States. Needman, MA: Babson Survey Research Group.

[2] Attewell, P. (1992). Technology diffusion and organizational learning: The case of business computing. Organizational Science, 3(1), pp. 1-19

[3] Bradford, M., \& Florin, J. (2003). Examining the role of innovation diffusion factors on the implementation success of enterprise resource planning systems. International Journal of Accounting Information Systems, 4(3), 205-225.

[4] Bradley, J., \& Lee, C. C. (2007). ERP Training and User Satisfaction: A Case Study. International Journal of Enterprise Information Systems, 3(4), 33-50.

[5] Brancheau, J. C., \& Wetherbe, J. C. (1990). The Adoption of Spreadsheet Software: Testing Innovation Diffusion Theory in the Context of End-User Computing. research-article.

[6] Chan, S., \& Lu, M. (2004). Understanding Internet Banking Adoption and Use Behavior: A Hong Kong Perspective. Journal of Global Information Management, 12(3), 21-43.

[7] Chau, P. Y. K. \& Hu, P. J. (2001). Information Technology acceptance by individual professionals: A model comparison approach. Decision Science, 32(4), pp. 699-719

[8] Cooper, D.R and Schindler, P.S (2003).Business Research Methods: 8th edition, MC. Graw-Hill Publishing Ltd, New York.

[9] Cooper, R. B., and Zmud, R. W. (1990). Information Technology implementation Research: A Technological Diffusion Approach. Management Science, 36(2), pp.123-139.

[10] Greenhalgh, T., Robert, G., Macfarlane, F., Bate, P., \& Kyriakidou, O. (2004). Diffusion of Innovations in Service Organizations: Systematic Review and Recommendations. Milbank Quarterly, 82(4), 581-629.

[11] Henriksen, H. Z. (2006). Motivators for IOS Adoption in Denmark: Journal of Electronic Commerce in Organizations, 4(2), 25-39.

[12]Hu, J. P., Chau, P. Y. K., Sheng, O. R. L. \& Tam, K. Y. (1999). Examining the Technology Acceptance Model using physician acceptance of telemedicine technology. Journal of Management Information Systems, 16(2), pp. 91-112

[13]Hu, P., J., Clark, T., H.,K. \& Ma, W., W. (2003). Examining Technology acceptance by school teachers; a longitudinal study. Information \& Management, 41, pp. 227-241

[14] Jeyaraj, A., Rottman, J., Lacity, M. (2006). A Review of the predictors, linkages, and biases in IT innovation adoption research, Journal of Information Technology, 21, pp. 1-23

[15]King, W. R., \& He, J. (2006). A meta-analysis of the technology acceptance model. Information \& Management, 43(6), 740-755.

[16] Lau, S. \& Woods, P. C. (2008). An investigation of user perceptions and attitudes towards learning objects. British Journal of Education Technology, 39(4), pp. 685-699

[17] Laudon, K., and Laudon, J. (1996): Management Information Systems Organization and Technology. Prentice Hall International, Inc Simon and Schelster Company.

[18] Lee, C. P., \& Shim, J. P. (2007). An exploratory study of radio frequency identification (RFID) adoption in the healthcare industry. European Journal of Information Systems, 16(6), 712-724.

[19]Lippert, S. K. \& Govindarajulu, C. (2006). Technological, Organizational, and Environmental antecedents to web services adoption. Communications of the IIMA, 6(1), pp. 147-160. Available at: http://scholarworks.lib.csusb.edu/ciima/vol6/iss1/14

[20] Ministry of Information \& Communications. "National Information \&Communications Technology (ICT) Policy", (2006): Retrieved 5/3/2008 from http://www.information.go.ke

[21] Ministry of Planning and National Development. Meru North District Development Plan (2002-2008). Nairobi: Government Printer.

[22] Mugenda O.M. and Mugenda A. G. (1999). Research Methods: Quantitative and Qualitative Approaches, Acts Press, Nairobi.

[23] Mugenda O.M. and Mugenda A. G. (2003). Research Methods: Quantitative and Qualitative Approaches, Acts Press, Nairobi.

[24] Muhunyo, G. (2008, June 29). College Saves Schools from Dishonest dealers. The Sunday Standard: BizBytes , p. 6.

[25] Mukama E. and Andersson S.B. (2008). Coping with change in ICT-based learning environments: newly qualified Rwandan teachers' reflections. Journal of Computer Assisted Learning 24 (2) , 156-166

[26] Mustonen-Ollila, E., \& Lyytinen, K. (2003). Why organizations adopt information system process innovations: a longitudinal study using Diffusion of Innovation theory. Information Systems Journal, 13(3), 275-297.

[27] Ndungu, P.M. (2005). A framework for Implementation of IT in Kenya High Schools Focusing on sustainability. Unpublished M.Sc. Project, University of Nairobi.

[28] O'Brien, J. (2000): Management Information Systems: Managing information Technology in the Internet Worked enterprises. Golgotia Publications; New Delhi.

[29] Obura, et al. (2003). The Winning Formula of Computers for Schools Kenya. International Development Research Centre, pp.16-26.

[30] Omolo, G. (2003). Factors Affecting Information and Communication Technology Implementation in Secondary Schools in Nairobi: Unpublished MBA Project, UON

[31]Pan, M. J., \& Jang, W. Y. (2008). Determinants of the Adoption of Enterprise Resource Planning Within the Technology-Organization-Environment Framework: 


\section{International Journal of Science and Research (IJSR) \\ ISSN (Online): 2319-7064 \\ Index Copernicus Value (2015): 78.96 | Impact Factor (2015): 6.391}

Taiwan's Communications Industry. Journal of Computer Information Systems, 48(3).

[32] Park, S. Y. (2009). An analysis of the technology acceptance model in understanding university students' behavioural intention to use e-learning. Educational Technology \& Society, 12 (3), pp.150-162.

[33] Reidlinger, D. and Weir, H. (1995). "The Information Highway and Canadian Education: Discussion of Issues Policy Recommendation", Paper prepared on behalf of Canadian Education Net Coalation, the schoolnet National Advisory Board and Senator Alliance (Ottawa: Canada).

[34]Rogers, E. M. (1983). Diffusion of Innovations. 3rd edition. The free Press, New York.

[35] Ryberg, T. \& Larsen, M. C. (2008). Networked identities: understanding different types of social organisation and movements between strong and weak ties in networked environment. Journal of Computer Assisted Learning 24, 103-115.

[36] Seers, A. (2007). Management education in the emerging knowledge economy: Going beyond those "who can, do; those who can't teach". Academy of Management Learning \& Education, 6(4), pp. 558-567

[37] Tornatzky, L., and Klein, K. (1982). Innovation Characteristics and Innovation AdoptionImplementation: A meta Analysis of Findings, IEEE Transactions on Engineering Management 29 (1), pp $28-45$.

[38] Vasudevan, V. (2001). AWeb Services Premier. URL: Http://www.xml.com/pub/a/2001/04/04/webser ver/index.html

[39] Watkins, G. Leigh, D., and Triner D (2003): Assessing Readiness for E-learning. Retrieved 10/11/2005 from http://www.isp.org/pdf/suggested reading/Vol 1704-66.pdf.

[40]Zhang, C., Cui, L., Huang, L., and Zhang, C. (2007). Exploring the role of Government in information Technology diffusion: An empirical study of IT Usage in shanghai firms. In McMaster, T., Wastell, D., Ferneley, E., \& DeGross, J. Organizational Dynamics of Technology-Based Innovation: Diversifying the Research Agenda (eds). International Federation for Information Processing (IFIP), 235, pp. 393-408, Boston, Springer. 